\title{
Is a Mobile Phone a Disruptive Innovation in the Workplace?
}

\author{
Mohd Fuaad Said, ${ }^{1 *}$ and Khairul Akmaliah Adham ${ }^{2}$ \\ ${ }^{1}$ Faculty of Economics and Management, Universiti Putra Malaysia, Malaysia \\ ${ }^{2}$ Faculty of Economics and Muamalat, Universiti Sains Islam Malaysia, Malaysia
}

\begin{abstract}
Extant literature on technology adoption in the workplace generally analyses a single technology, thereby preventing us from a comprehensive understanding about the use of multiple technologies at work. As the usage of mobile devices becomes ubiquitous, knowing how the use of multiple technologies influence individual and group-related tasks is becoming more critical. Therefore, the objective of this study is to understand how managers perform their duties and functions and what technologies are utilized. This study adopts a qualitative study design by conducting in-depth interviews with eight managers employed in the public sector. We found four categories of convergence of mobile and fixed technologies in the workplace: supplementary, complementary, high-degree of integration, and full integration. The technology convergence is mainly influenced by the nature of the managerial work. Most importantly, mobile device is yet a disruptive innovation in the workplace, although its full integration with the fixed technology can be promoted.
\end{abstract}

\begin{abstract}
Abstrak: Literatur mengenai adopsi teknologi di tempat kerja umumnya menganalisa teknologi tunggal, sehingga membatasi kita dari pemahaman komprehensif tentang penggunaan teknologi ganda di tempat kerja. Sejalan dengan meluasnya penggunaan perangkat mobile di mana-mana, pemahaman tentang bagaimana penggunaan teknologi ganda mempengaruhi tugas-tugas individual dan kelompok terkait menjadi lebih kritis. Oleh karena itu, tujuan penelitian ini adalah untuk memahami bagaimana para manajer melaksanakan beberapa tugas dan fungsi mereka dan teknologi apa yang digunakan. Penelitian ini mengadopsi desain studi kualitatif dengan melakukan wawancara mendalam dengan delapan manajer yang bekerja di sektor publik. Kami menemukan empat kategori konvergensi teknologi mobile dan tetap berada di tempat kerja: suplementer, komplementer, tingkat integrasi tinggi, dan integrasi penuh. Konvergensi teknologi terutama dipengaruhi oleh sifat pekerjaan manajerial, meskipun integrasi penuhnya dengan teknologi tetap dapat dipromosikan. Paling penting, sekalipun demikian, perangkat mobile merupakan suatu inovasi disruptif di tempat kerja.
\end{abstract}

Keywords: desktop computing; disruptive innovation; managerial work; mobile technology; qualitative study

JEL classification: M100, M150, M190

* Corresponding author's e-mail: fuaad@upm.edu.my 


\section{Introduction}

Mobile technologies have become ever more ubiquitous in the workplace and people's personal lives. While previously the technologies for internet access and mobile voice usage have been largely separated, in recent years the convergence of mobile phones and fixed and wireless internet has rapidly increased. The evolution in physical convergence and the innovation of mobile (smartphones) and computing devices (tablet, notebook, desktop computers) has resulted in a revolution in the way people do their work and live their lives. This revolution gains momentum with the rapid development of peripheral devices and apps that provide greater connection between mobile devices and assist them in capturing, storing and displaying multimedia data (Verizon's Your Guide 2013). This leads to the integration of mobile devices and apps into aspects of people's lives such as in their travel and leisure, education, and finance, and now smartphones come in the form of eyeglasses and wristbands (J. W. Thompson Company 2013).

One of the most significant aspects of converging mobile and fixed technologies is in the workplace. The use of mobile phones, in addition to stationary workplace computing equipment is on the rise. A survey by the Forrester institute found that of 9,766 IT workers from 17 countries, approximately 48 percent utilised smartphones for work and another 21 percent used tablets for the same purpose (Schadler 2013). More significantly, such adoptions were mainly initiated by the employees, with their organisations having no influence over the workplace's use of mobile applications. A Forrester's 2012 report indicated that 20 percent of 320 surveyed employees were willing to incur personal ex- penses to allow them to utilise their own choice of mobile devices to support their tasks at work. This shows the importance of choosing the right technology to ensure a fit with the tasks that need to be performed. Their willingness to spend their own money to buy the mobile devices indicates the high level of dependency and significance placed by these employees on these devices.

With the increase of technology convergence in the workplace, the ubiquitous use of mobile phones, the decrease in the price of these technologies, and the increased coverage of mobile network services, we may question as to whether the mobile platform will become a disruptive innovation and replace fixed office desktops and other computing technologies, or will it continue to coexist and converge with fixed computing at the workplace. Within this context, a disruptive innovation refers to a technology that ultimately supersedes the current dominant technology in use (Valacich and Schneider 2010).

Most previous technology adoption studies analysed a single technology. For example, Yuan et al. (2010) and Kim (2008) examined the use of mobile phones. Such a research design does not allow a comprehensive understanding on how the use of multiple technologies affects peoples' work. A lack of understanding among top management of the multiple technological usages can lead to difficulties in planning their organisations' future technology infrastructure. Inappropriate planning can result in costly and severe losses of time and resources. More importantly, the organisations are also unable to support their managers' work-related activities, thus hindering their effectiveness at work.

With the above preliminary, the objective of this study is to understand how man- 
agers perform their activities and functions and what technologies are utilised. The study is guided by the following research questions: 1) what is the current usage of fixed and mobile technologies/applications in support of managerial functions? 2) What is the level of multiple technologies' convergence in the workplace? 3) What are the factors that influence multiple technologies' convergence in the workplace? 4) How does the use of multiple technologies influence their managerial work performance? In this study, we use the term managerial functions to refer to the activities of planning, organising, leading and controlling. Activities refer to the specific tasks that managers perform in support of their managerial functions, which include writing memos, making phone calls, and attending meetings.

\section{Literature Review}

Innovation refers to the adoption and usage of something new by an individual, organisation, or society (Rogers 1995; Tornatzky and Fleischer 1990). Within the context of an organisation, innovation can be categorised according to the degree of change it brings to the organisation. Radical, revolutionary or disruptive innovations result in business transformations in an organisation or industry, and lead to major changes in current business processes that can displace existing dominant products on the market. These changes create significant uncertainties within an organisation and an industry (Tushman and Anderson 1986). Such disruptive innovations are in contrast to the incremental types of innovation, which result from minor organisational changes aimed at improving the existing business processes or products (Dewar and Dutton 1986). Regardless, innovation is a process that requires top management to make decisions on its adoption and implementation.

\section{Diffusion of Innovation and Disruptive Innovation}

Making decisions on what technology to adopt is a complex task and many organisations have failed to realise the opportunities provided by a newly introduced technology (Valacich and Schneider 2010). According to Rogers (1995), at the industry level of analysis, a new technology goes through four stages of adoption when introduced to the market. At first, a few individuals (innovators) will adopt this innovation. Next, this technology will attract the attention of a larger group of users/customers (early adopters) and by then it becomes more popular and its adoption rate increases to reach the highest point with the main group of users/customers (early majority). Finally, this rate begins to level off and decline, with only the last group of users/customers (laggards) utilising it.

However, a technology can be disruptive and its introduction can create disorder in the market. This introduction can lead to the displacement of an existing technology, or in the extreme case, it can cause the collapse of the entire industry. Examples of such innovation are cars replacing horses and carts, or computers replacing typewriters. On the other hand, a new technology can also coexist with current technologies for a long period, such as jet and piston-engines. In the case of mobile devices, they become disruptive if their usage replaces the use of fixed devices altogether (e.g. fixed phones, desktop computers and televisions). If the use of mobile devices supplements or complements the usage of fixed devices, they are considered incremental innovations. 


\section{Technology Adoption and Convergence Studies}

According to Wolfe (1994), technology adoption studies are divided into three types. Innovativeness research usually focuses on examining factors that influence users to adopt a particular technology. Diffusion research, on the other hand, emphasizes the trend of technology adoption among a specific adopting population, while process research concentrates on the activities of adopting and implementing technologies by users. The unit of analysis of these technology adoption studies can be the society, organization, group, or individual user. Organization-level adoption studies address the concerns of organizations in adopting technologies, including organizational factors that influence decisions to adopt (Damanpour 1987), processes that organizations go through in adopting a new technology (Tornatzky and Fleischer 1990), and approaches to selecting the appropriate technology for the organizations (Noori 1990). Within this group of inquiries, some studies focus on companies in which mobile technologies are their core business (e.g. Shamshubaridah et al. 2010; Said and Adham 2010; Said et al. 2013). For example, Said et al. studied the evolution and strategies of four telecommunications companies in $\mathrm{Ma}-$ laysia.

Studies that focus on individual users have increased in popularity since the 1990s. This stream of technology adoption studies has since supported the evolution of the Technology Acceptance Model (TAM). The original TAM (Davis 1989) evolved into several models including TAM2 (Venkatesh and Davis 2000), Unified Theory of Acceptance (UTA) and Use Theory (UT) (Venkatesh et al. 2003), and TAM3 (Venkatesh and Bala 2008). These studies focus on the individual's usage of technology in organizations. These models of technology adoption are also utilized in studies involving external users, which focus on the consumers' adoption of technology, such as the adoption of mobile banking, internet shopping, online marketing and e-auctions (See, Zhou et al. 2010; Zhou 2014).

The studies on mobile technology adoption have gained more interest, especially since the mid-2000s. They can be classified into five groups. The first group attempts to identify factors that influence the intention and actual usage by individual users. For example, studies by Yuan et al. (2010) and Kim (2008) are related to mobile technology's adoption in the workplace. According to Kim (2008), moderating the effects of job relevance is significant in mobile devices usage at the workplace, and the intention to use is also significantly affected by the corporate sponsorship of mobile programs. However, Kim's study does not identify the task-related purpose of using mobile phones at work. In 2010, Yuan et al. (2010) focused on task-related characteristics and how they fit with the mobile's functions. However both Kim and Yuan et al. (2010) concentrated exclusively on mobile technologies, thus, their findings do not provide a full picture on the use of technologies in the workplace, as work is supported not only by mobile phones but also other devices (e.g. laptops) in the office as well as at home.

The second group of mobile technology's adoption research focuses on human-technology interaction. Within this research group, a review by York and Pendharker (2004) on human-computer interaction in mobile computing emphasized the importance of the proper integration of technologies into the work to avoid hindering the efficiency and effectiveness of task completion at the work- 
place. Therefore, there is a need to look into specific task characteristics and the context of the work as they relate to the adoption of technologies, so that the adoption becomes an enabler instead of a hindrance to the task's completion. A study by Schrott and Glucker (2004) analyzed multiple technologies at the workplace, although their study did not focus on specific and actual task-related activities that are more complex and require more intense interactions between workers.

The third group of research examines the use of mobile phones for work-related issues during work versus non-work hours (Hislop and Axtell 2011; Townsend and Batchelor 2005). Based on the boundary theory perspective, this research group discussed issues of work-family life balance related to the usage of mobile technologies. Hislop and Axtell's review of the literature indicated that the usage of mobile technologies is viewed from multiple perspectives: a) mobile technologies blur the work and non-work boundary thereby diminishing family-time value; b) mobile technologies are feasible tools for organizing work, and thus able to support a work-family balance; c) mobile technologies are not the deciding factor in influencing the work-family balance, rather their usage and influence are decided by the individual user's preference of when, where, and what purpose he/ she will use the technologies.

Concurrent with the development of technology adoption models by individual users in the mid-1990s, and the evolution of human-computer interaction research, a group of research focusing on the task-technology fit began to emerge (Goodhue and Thompson 1995). The issue of fit attracts the attention of the fourth group of research on mobile technologies adoption. By the mid-2000s, the task-technology fit model was applied to ex- plain the usage of mobile technologies and later evolved into the fit-viability model, which integrates organizational dimensions of technology usage (Liang et al. 2007; Liang and Wei 2004). The fit-viability model suggests the importance of three forms of technology adoption readiness: a) the readiness of the organizational environment to accommodate mobile technology usage, b) the readiness of the end users to utilize mobile technology, and c) the readiness of the organizational infrastructure to support the usage of mobile technology. The model suggests that tasks must have elements of mobility and reachability to allow them to be effectively supported by mobile computing (Liang et al. 2007; Liang and Wei 2004).

Finally, the fifth group of research on mobile technology's adoption emphasizes the issue of digital convergence, either the convergence of technologies in the form of devices, applications, or networks. Most recently, smartphones with fully-fledged computing abilities are considered the most converged mobile and computing devices (PC Magazine Encyclopaedia 2014). Similar to the emergence of theories of user acceptance and task-technology-fit, studies in this group begin to gain interest in the mid-1990s. While earlier, digital convergence studies focused on defining the terms and related organizational strategies to prepare for the impending converging technologies (Yoffie 1996), more recently, this group of studies has highlighted the factors that influence the degree of convergence. For example, according to Yeon and Hwang (2011), user and organization convergence readiness, user satisfaction, and user task performance are factors contributing toward the level of digital convergence in the industry. 
In summary, while previous research highlighted the need to address the task-technology-fit, most focused mainly on examining the usage of a single technology in support of selected tasks performed at a particular point in time. There is a need to analyze the use of multiple technologies that assist in the completion of managerial work. A lack of understanding about the overall managerial work distorts the view of how technologies support the completion of these works. This fragmented view of what managers do can lead to misinterpretations about the tasks performed by them and the technologies that can support (fit to) these tasks. This research overcomes the limitations of the previous studies by analyzing the use of multiple technologies in support of the whole span of managerial work. The study's outcome highlights the level of technology convergence in the context of managerial work.

\section{Methods}

This study utilized a qualitative research design because it was the most appropriate for addressing our research objectives, which required an understanding of the use of technologies within the contexts of the managers' work. According to Merriam (2009), the use of a qualitative study is appropriate when examining a phenomenon within a context, as in the case of our study. In achieving our research objectives, we utilized in-depth interviews to collect data from the managers, specifically, four senior and four junior executives employed in the public sector. This sector was selected mainly because we had direct access to the study's participants. During the interviews, the participants were requested to describe their job-related activities and their use of technology in supporting these activities. They were also asked to share their experiences in regard to the challenges involved in using the various technologies at their workplace. In support of the interview process, this study utilized an interview protocol comprising of open and semistructured questions. All the interviews were conducted during the months of January and February 2015.

Managerial-level participants were chosen for this study because they assume many roles and perform many functions, all of which require a great degree of communication and coordination, and a heavy use of communications media. Thus, their activities are likely to be affected by technological innovations in the workplace. Both senior and junior level managers were selected to allow us to make a comparison of the usage between different seniority levels and age groups. We assumed that a more senior manager would be doing a higher level of managerial work, while the younger executive would handle more operational work. This comparison enabled us to observe the use of the technologies amongst senior and junior managers. Participants were selected based on personal contacts and the snowballing technique. Table 1 shows the profiles of the participants in the study. As shown in Table 1 , the study included eight managers employed in four different offices in the public sector.

All the interview data were analyzed using an open-coding procedure, which was then followed by a coaxial coding technique similar to the analysis performed in grounded theory studies (Strauss and Corbin 1990; Merriam 2009). Coding and analysis of the participants' data were performed immediately after the data were obtained, and only after its completion did the data collection and analysis for the next participant began. This procedure followed the recommendation of 
Table 1. Profile of Participants

\begin{tabular}{|c|c|c|c|c|}
\hline \multirow[b]{2}{*}{ Respondent } & \multicolumn{2}{|c|}{$\begin{array}{c}\text { Security Unit- Government Research } \\
\text { Agency }\end{array}$} & \multicolumn{2}{|c|}{$\begin{array}{l}\text { Environmental Unit-Government } \\
\text { Research Agency }\end{array}$} \\
\hline & Mohamed & Maria & Rashid & Norman \\
\hline Position & Deputy Director & Asst. Director & Deputy Director & Asst. Director \\
\hline Age (year) & 44 & 29 & 46 & 29 \\
\hline Gender & Male & Female & Male & Male \\
\hline Year of service & 19 & 5 & 19 & 5 \\
\hline \multirow[t]{3}{*}{$\begin{array}{l}\text { Educational } \\
\text { background }\end{array}$} & $\begin{array}{l}\text { Bachelor in } \\
\text { Applied Sc.; }\end{array}$ & $\begin{array}{l}\text { Bachelor in } \\
\text { Economics }\end{array}$ & $\begin{array}{l}\text { Bachelor in } \\
\text { Economics; }\end{array}$ & $\begin{array}{l}\text { Bachelor in } \\
\text { Marine Science }\end{array}$ \\
\hline & M.Sc. Tech Studies & & MBA & \\
\hline & \multicolumn{2}{|c|}{$\begin{array}{l}\text { Academic Research Unit-Research } \\
\text { University } 1\end{array}$} & \multicolumn{2}{|c|}{$\begin{array}{l}\text { Academic Research Unit- } \\
\text { Research University } 2\end{array}$} \\
\hline Respondent & Amy & Idris & Kay & Jamie \\
\hline Position & Deputy Dean & $\begin{array}{l}\text { Asst Admin } \\
\text { Officer }\end{array}$ & Deputy Dean & Admin Officer \\
\hline Age (year) & 39 & 29 & 45 & 32 \\
\hline Gender & Female & Male & Female & Female \\
\hline Year of service & 15 & 7 & 15 & 8 \\
\hline $\begin{array}{l}\text { Educational } \\
\text { background }\end{array}$ & Ph.D. & STPM & Ph.D. & $\begin{array}{l}\text { Bachelor in } \\
\text { Accounting }\end{array}$ \\
\hline
\end{tabular}

Merriam (2009), who suggested that the data analysis be done simultaneously with the data collection, or immediately after collection. According to Merriam (2009), this approach toward data analysis helps to make the data analysis manageable and avoids the potential problem of researchers being drowned in their data.

The data analysis focused on answering the research questions, which included determining the managerial functions and usage of the fixed and mobile technologies/ applications in support of the functions, as well as the factors that influenced the use of the technologies. The themes that were generated were interpreted into categories, each of which had specific characteristics or items. These emergent categories however, existed in continuum from low convergence to highly integrated. These emergent categories constitute the main findings of the study.

After interviewing the seventh and eighth participants, the process was concluded because the gathered data had reached saturation point. This was the point at which no new insights were identified from the data 
being collected. Having reached this point, we could make an intelligent guess that interviews with the ninth and subsequent participants with similar characteristics to the managers included in our study would give us the same findings.

\section{Findings}

This section first describes the nature of the work of the participants and their context. This information provides the basis for examining the types and patterns of technology usage in their workplaces. All the participants have fixed computers and internet access in their offices and all use smartphones.

\section{Nature of Managerial Works and Their Contexts}

Rashid and Norman work in the environmental unit of a government research agency. The unit's responsibilities are to formulate government policies and devise national plans for the country's environmental and natural resources. It is also the unit's duty to monitor the implementation plans of relevant agencies and the budget for agencies involved in environmental activities. Each year, it handles a significant budget related to proposals on the environment. The proposals include those from international bodies. In formulating the policy, the unit requires information from multiple government agencies so that the draft plan can be completed. This not only involves public agencies, but also those from the private sector. The general public are also encouraged to provide feedback on the unit's proposed policies. Discussions are conducted with these parties to identify which proposals and plans have the highest positive impact on the nation's environment, and thus should be given priority, as the unit's budget is limited. The environ- mental unit employs one director, one assistant director, and eight officers.

Rashid's job is focused on policy formulation, while his subordinates are in charge of the paperwork for the formulation of policies. Norman's responsibilities are to coordinate budget decisions and supervise project implementation. He also puts together information on reviews for policymaking and implementation. Norman prepares reports and outputs for higher-level management, coordinates meetings among the relevant agencies, and prepares minutes. $\mathrm{He}$ is also involved in collecting the findings of research into marine and land issues.

Like Rashid and Norman, Mohamed and Maria work in the same government research agency, but in a different unit. The unit is responsible for policymaking in regard to national defence and the security of the nation. This includes ensuring that projects for national defence and security activities are well-planned and properly implemented. It also has the authority to evaluate submitted proposals related to its areas of responsibility, approve and prioritize these proposals, and monitor the progress of the implemented proposals. It also needs to ensure that the proposed defence and security projects have a reasonable completion schedule, provide added-value to the nation, and carry minimal wastage in their implementation. The unit has ten operational staff and two support employees.

Mohamed acts as one of the policymakers on national defence and security related activities, while Maria's responsibilities are to coordinate decisions made on the budget and supervise project implementation. She also needs to put together information on reviews for policymaking and implementation. 


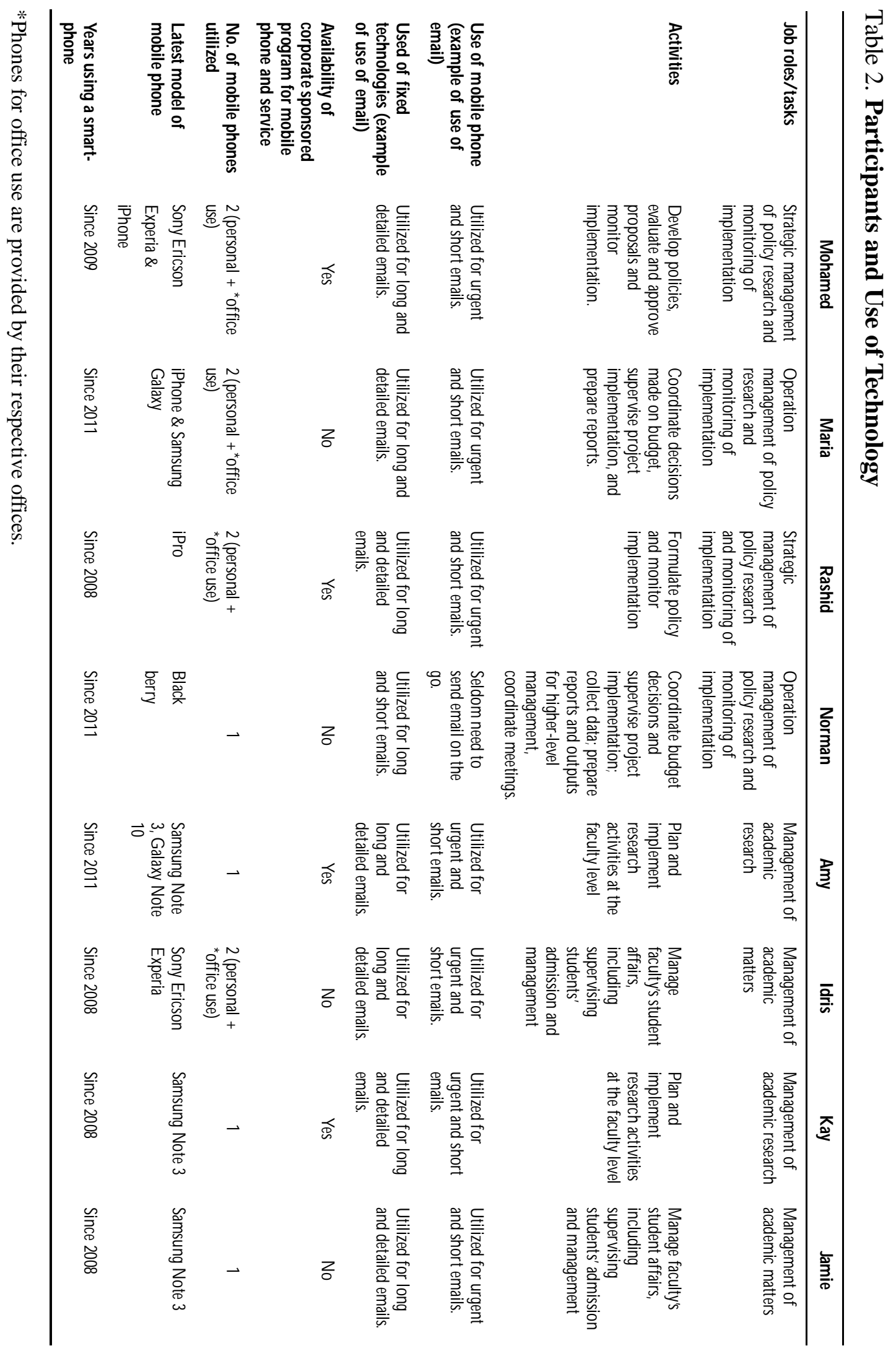


Amy and Idris, on the other hand, are both from the business faculty of a research university. Amy is an academic with managerial responsibilities, while Idris is a full-time university administrator assigned to the academic unit of the faculty. Amy's responsibilities are to plan and implement research activities at the faculty level, while Idris' tasks are to manage the faculty's student affairs. In planning and implementing research activities at the faculty level, Amy's unit requires information from both internal and external parties (the university, grant providers, and industries). Her unit comprises herself as the research manager, one research officer, and three administrative support staff. Idris' unit supervises the students' admission and management, and thus requires information from both internal and external parties (students, the university, and industries). His unit comprises the academic affairs manager, two officers, and four administrative support personnel.

Kay and Jamie are both from the graduate school of business of another research university. Like Amy, Kay is also an academic who leads a unit responsible for planning and implementing research activities at her graduate school. In carrying out its duties, Kay's unit also requires information from both internal and external parties (the university, grant providers, and industries). The unit comprises herself as the research manager, one research officer, and one administrative support person. On the other hand, Jamie works as an officer in the student affairs unit, which manages the students' admission and management. This unit comprises an academic affairs manager, an officer, and an administrative support person. It also requires information from both internal and external parties (students, the university, and industries) to manage its activities. Table 2 shows the types of technologies that the managers employ at work.

\section{Usage of Fixed and Mobile Technologies and Applications in Support of Managerial Functions}

Managers utilize technologies in the workplace to support the basic managerial functions of planning, organizing, leading, controlling, and decision-making. Most importantly, the employed technologies allow for communication between the managers and their superiors, subordinates and outsiders, including their customers. Communication related activities include getting, providing, monitoring, disseminating, and verifying information. For example, the activity of information monitoring and dissemination for Amy usually involves her communicating with her subordinates. On the whole, the most important mobile application utilized by the managers is e-mail, via their office desktop computers or mobile phones, which they use in support of their daily work. Managers often utilize e-mail through their mobile phones, especially, when they are at home or away from the office. In such instances, the managers not only read their e-mails on mobile phones but also write short replies or instructions to the senders or other relevant people if they are urgent.

Mohamed also utilizes his mobile phone for information capturing, but through the use of the mobile phone's video and still cameras. The gathering of data via photographs and videos is part of his managerial works related to monitoring and controlling. As mentioned by Mohammed, he took photos of certain security incidents for recording purposes and to verify information provided by others. 


\section{Table 3. Summary of Types of Technologies in Support of Managerial Functions and Activities}

\begin{tabular}{ll}
\hline \multicolumn{1}{c}{ Types of Applications } & \multicolumn{1}{c}{ Functions and Activities } \\
\hline $\begin{array}{l}\text { E-mail, messenger (WhatsApp, Line), SMS, } \\
\text { phone call }\end{array}$ & $\begin{array}{l}\text { Communicating, disseminating information, } \\
\text { following-up on communications, } \\
\text { monitoring and controlling }\end{array}$ \\
Facebook & $\begin{array}{l}\text { Communicating and socialising via online } \\
\text { media }\end{array}$ \\
Web browser & Gathering information for decision making \\
Calendar, to-do-list, planner, alarm & Organising and planning \\
Camera, photo album, video camera & $\begin{array}{l}\text { Capturing information, monitoring and } \\
\text { controlling }\end{array}$ \\
$\begin{array}{l}\text { Dropbox, google drive or other cloud } \\
\text { accounts }\end{array}$ & Sharing files, supporting work mobility \\
MS Office documents & Editing and viewing information \\
\hline
\end{tabular}

Some of the communications by the managers are directly related to their activities as leaders. For example, Rashid performs follow-ups with his subordinates through the use of his mobile phone, which is indicative of his efforts to keep his subordinates on track. This is part of his leadership function as a manager in his department. These follow-ups also serve as a motivating mechanism to encourage his subordinates to achieve the desired performance. For Amy, sometimes she uses the desktop computer to send long and detailed communications via e-mails, and utilizes her smart phone to follow-up on prior communications.

Outside of communicating information, the managers are also involved in organizing, planning, and making decisions. Mobile organizers are the second most utilized application by the managers after e-mail. Except for Norman, who uses a physical organizer, all the managers use a calendar and/ or related apps in their mobile phones to sup- port their daily scheduling. Rashid describes his use of the mobile organizers:

Sometimes I have many meetings to attend, and some meetings I have to monitor. Therefore, I would include in my organizer, the schedule of my own and my staff members' meetings. My organizer is linked with my personal assistant's computer. My personal assistant can update the organizers which syncs with my phone. I can also manage the calendar myself.

The current usage of multiple technology in support of managerial functions is mainly converging, in which stationary computers and peripheral equipment are utilized in combination with mobile devices. The latter technologies are operated mainly for short and urgent communications. The mobile technologies are also useful in supporting work performed outside the office, such as while travelling, or meetings outside of the office. In general, mobile technologies directly support a number of managerial works, and complement the managers' use of fixed technologies in the office. 


\section{Level of Convergent Technologies Usages}

The level of convergence exists in a spectrum, and can be categorized into supplement, complement, high-degree of integration, and full-fledged integration. The supplementary use of mobile devices indicates their adoption is in addition to the fixed technologies in the office. Norman, who is office-centric in terms of his physical work-location, describes a supplementary type of usage:

I use the mobile phone when I am outside the office. For example, while attending a workshop at a botel or another department, if I receive an e-mail and it is urgent, I will read it, and if necessary, I will respond to it quickly. If not, I will take note of it. Once I arrive at my office, then I will take the necessary action, and if I need to send or to forward something, I use my PC because my phone has limited capability. All my work is done in the office. Sometimes I will do a little at home but not too often. I only work. at home if there is an urgent need. My smartphone's features are limited; the screen is small.

Norman however agrees that the use of mobile phones can increase efficiency in his work because he can prepare in advance tasks that need to be performed. Without a mobile phone, vital information cannot be obtained in advance, thus slowing his work preparations. His immediate superior prefers to use e-mail for communicating. This influences the choice of technology used for communicating by Norman. For his level of work, Norman is office-centric, thus, there is no need for him to utilize mobile phones to support his work, other than for communications.

A complementary integration of mobile phones in the workplace occurs in the case of Rashid. Complementary integration refers to pairing the usage of mobile and fixed technologies. Rashid relates the integrated use of the two types of technologies from home to office and back.

Once I reach my office, I will check the e-mails through my mobile phone. Then, when there are things to type, I will use my desketop PC since it is more comfortable. Using a mobile phone can sometimes be a bit difficult. After that, I will always have a meeting in the morning, or in the afternoon. Then, after five, when I am at home, I check the mobile phone to make sure all is done and there are no outstanding tasks. I use my mobile phone all day, even during meetings, depending on need. If I am in a meeting, if there are urgent things to be done, I will respond through the mobile phone. If I have a meeting or I am not in the office and there are e-mails coming in, I reply quickly through my mobile or sometimes, when I need to give instructions to my officers, I will forward the instructions to them.

The integrated use of desktop and mobile applications is fully supported by synchronization of the apps in smartphones. While Rashid's use of a mobile phone centres on the time of his meetings (replying and forwarding e-mails while being outside of his office), Jamie's use of her mobile phone focuses on the need to make calls, indicative of a more traditional role for mobile phones in support of her work. Jamie is not able to complete her job without her mobile phone as most of her daily tasks involve communicating with others, and thus to her a mobile phone is compulsory.

The phone is especially helpful in getting additional information, if I need to call people [...] that's why I need to have my phone with me all the time [...] For example, yesterday I left my phone at home, by the afternoon, I ran back to get it. I lasted only half a day [without the mobile phone], and that is because there was a meet- 
ing in the morning. Then I went back home to get it because I had to make calls to some colleagues and to the dean. I do not memorize phone numbers. Without the phone, my work is unbearable [...] back then, I could live without a phone, but now, I am too dependent on the device.

Kay also has to have her smartphone with her during office hours and at home, especially as she does not have an internet connection at home:

I cannot leave my phone behind because it is difficult to do my work as all the important phone numbers are listed on the device. I also receive many calls during my time at work, so the phone has to be around. I don't use my office desk phone or Facebook to communicate with others. I also do work at home and I don't have internet. So, I need to have the phone even at home. My phone is equipped with a cloud account sync, so I use it almost like a computer at home. Editing is one function I normally do not use when using my phone. At the office, I use it as a traditional phone unless I have meetings, then I access emails using the phone. Otherwise, I use the desktop.

From the above, the use of a mobile phone for verbal communication is essential especially when the office desk phone or social media is not utilized as a support medium for that purpose. For Maria, none of the technologies can be used exclusively on its own to assist in completing her office tasks. She needs a mobile phone for communication, a tablet computer for obtaining data during meetings or office presentations, and a desktop computer for editing and document preparation.

If there is no desktop, I will use the tablet instead. If it has the same software applications as the desktop, then it should not be any problem. But my tablet does not have the application to edit documents such as Word and Excel. I can only view the documents but I cannot edit them [through the tablet].

However, Maria stated that she must have access to all the different technologies during work. She cannot afford to go to work without her tablet computer, as she needs to bring the device to meetings and office presentations, particularly, as her office adopts a 'green office' concept of not producing any hardcopies of documents. She also needs to have her mobile phone around because she is required to communicate verbally and in short messages with co-workers and others from outside agencies. This indicates a high degree of integration of mobile devices into Maria's work.

For Mohamed, the use of a smartphone is also highly integrated with the technology in his office. He utilizes his smartphone while attending meetings because of his office's green policy, which compels his department members to minimize their use of paper at the workplace:

In the office, I usually use my mobile phone together with my desk.top computer because my phone allows me to access e-mails much faster than using the computer at the office [...] In every meeting, I carry with me my mobile device. For meeting purposes, we also take our mini ipads or galaxy notes to minimize the use of paper in the office.

Amy's use of her mobile phone is also highly integrated into her work:

So far, I only left my phone at home twice. It is a very important device for me. If I left it behind, I would immediately notice it is missing, because $I$ have this habit of having my phone around. So, it would be unlikely to be left bebind. If that happens, I would return to pick it up.

However, Amy's use of smartphones is more technologically advanced in compari- 


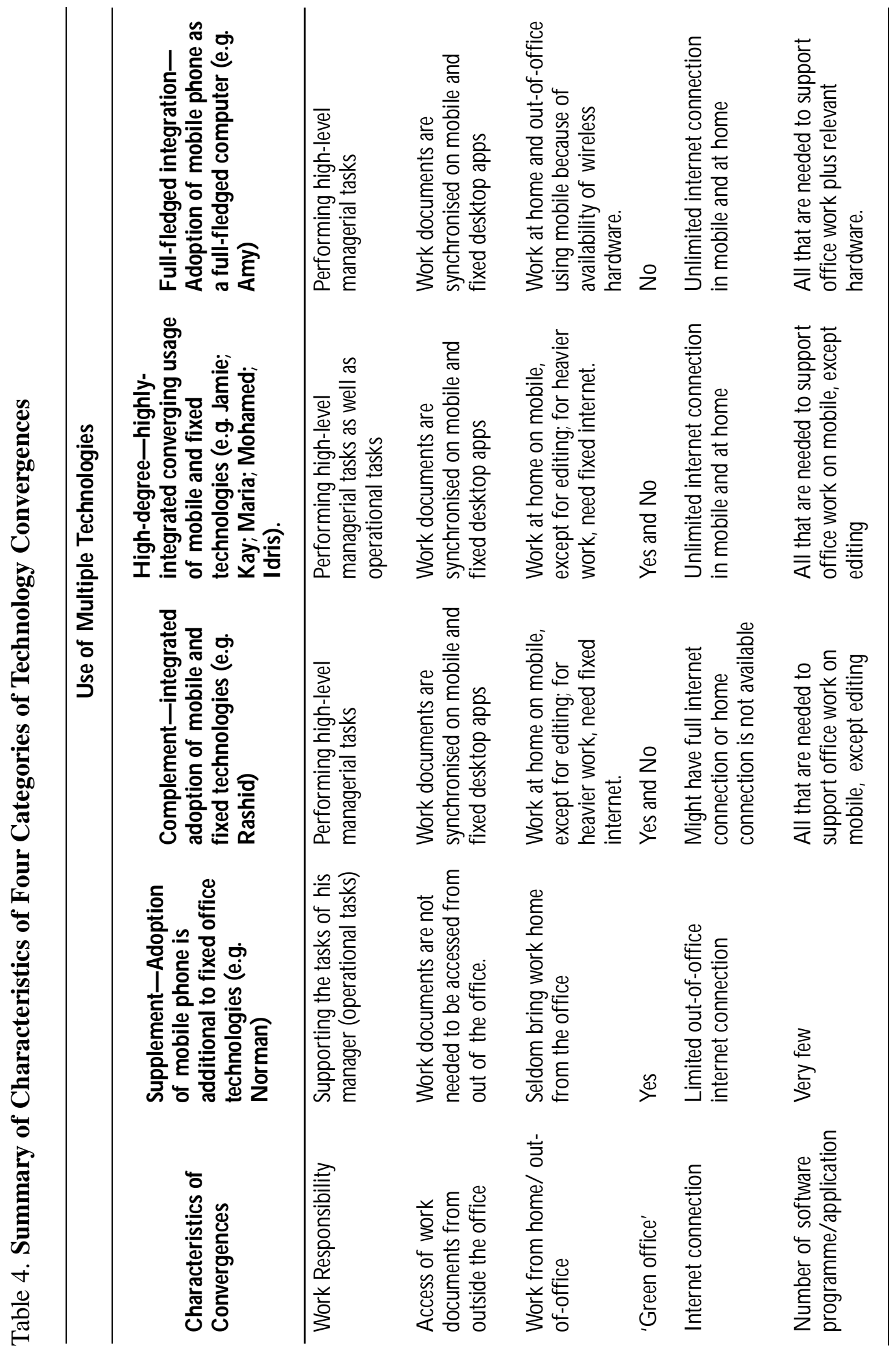


son with Maria's, including typing using a Bluetooth keyboard, which is an indication of her use of her mobile device as a full-fledged computer or workplace technology. Table 4 summarizes the characteristics of the categories of technology convergences.

\section{Factors that Influence Multiple Technologies Usage}

From their levels of technology convergence at work, we generated a classification of the factors that influenced the usage of multiple technologies in the workplace. These dimensions are: a) the nature of the work of the managers, b) the characteristics of the organizational support, c) the attributes of the managers themselves and their colleagues, and d) technological factors. The dimensions and their factors are shown in Figure 1.

The nature of the managers' work comprises of items related to the degree of mobility involved in their work and the degree of communication needed to accomplish their tasks. The higher the required degree of mobility and communication is, the more integrated the usage of mobile and fixed technologies is in the workplace.

The characteristics of organizations that support the high integration of mobile technologies and fixed technologies in the workplace includes the non-availability of secretarial assistance or support, as this forces the managers to be dependent on their mobile phones to assist them in organizing their own work. Therefore, in the case of these managers, their mobile and fixed technology convergence is not influenced by the readiness of their organizational environment but rather because of a lack of support for their necessary work functions. Rashid relates his issues with support staff:

Our unit is small and the agency is structured in an inverted pyramid. We have one clerical staff member, who we all share. So, a lot of work we have to do ourselves, without support staff.

Figure 1. Emergent Dimensions and Factors that Influence Multiple Technologies Usage in the Workplace

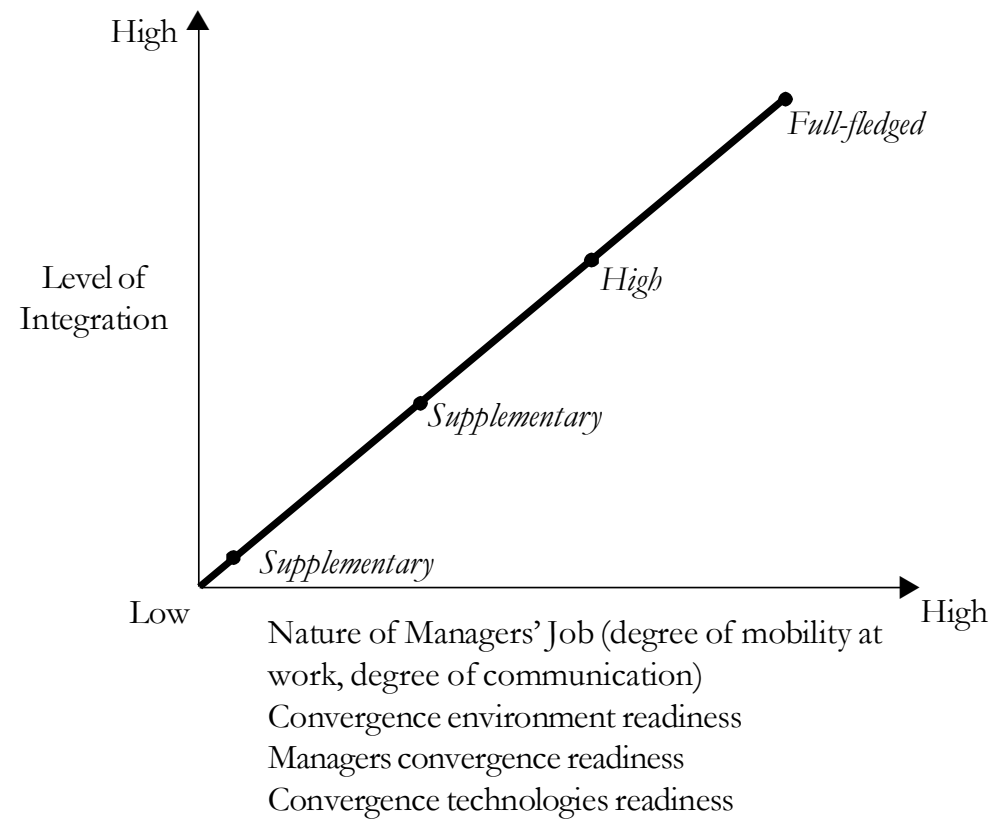


While the use of mobile organizers is also important for those who have secretarial help, it is less important for those whose location of work is physically tied to the office, as described by Norman:

I do a lot of work here in the office. For the bosses, they have many more meetings outside. Therefore, they have to have a planner or organizers so that they can easily plan their activities. For me, an organizer is not a necessity.

In this sense, the degree of mobile technology convergence is influenced by the level of office-centricness of the managers' work.

The managers' convergence readiness, however, seems to be influenced by the organization's convergence readiness. The availability of corporate sponsors for the devices or service bill payments, or both, supports the full-integration of mobile phones in these managers' work. The full-integration can also be induced by certain corporate policies, such as the green office project of Mohamed:

In this office, we are not encouraged to use new paper. We can only use recycled paper when we can confirm that the file is the finalized version that we want to print. Otherwise, we will just read the material on the computer. To minimize the use of paper, for meetings, everyone will bring their mini $i$ pads or galaxy notes.

The level of managers' convergence readiness is also influenced by the availability of internet access at home. This variable can be classified under the attributes of managers, when they utilize the internet in a proactive effort to support the completion of their work at home. Alternatively, it can be classified under the technological factors, when the availability is low due to the lack of service or coverage at home. Another form of inducement for internet adoption at home is the availability of corporate sponsorship in paying the internet service bills at the managers' residences.

\section{Use of Multiple Technologies and Managerial Work Performance}

All the study's participants are satisfied with their work performance where the use of mobile technologies is concerned. For some participants, their use of a smartphone directly addresses their concern for performance. Norman and Rashid feel that they need to stay up-to-date on their latest tasks for fear of being left out, and using e-mails after work through their mobile phone helps them to resolve this concern. As such, all are grateful for the use of the mobile technologies.

All the participants also agree with the efficiency afforded to them by their use of their smartphones, as mentioned by Mohamed:

A smartphone is an enabler as it makes it easier to do work and helps in improving productivity, and work efficiency. However, even if I did not have one, the work can still be done, but may require more time and I can become less efficient.

The efficiency afforded by the use of smartphones helps in many ways, including supporting certain decision making activities, as mentioned by Rashid:

In making decisions, I have to get information. With this smartphone, I can gather information faster. Let say, I need to decide something about management. If I do not have the phone, I have to discuss everything either in the office or wait till I get home to use the phone. However, when I have my smartphone, I can open my files and make the relevant review. The office can send me files wherever I am so I can check and make decisions. 
The use of a smartphone also improves their effectiveness at work. Rashid describes how his smartphone contributes to his effectiveness at work:

Being more efficient at work is one thing, the other is improved effectiveness. I can solve the issue that I want to solve faster, for example, earlier today, while I was away from the office I received an e-mail from my office instructing my group to prepare certain documents. So when I get back in the office, I already know what to do, which person will be in charge of what, I have already forwarded the information to my team, asking them to please prepare [...] So that when I am back in the office, I can move in straight to review, this is what I meant by effective.

For both Amy and Jamie, their dependency on their mobile phones is indicative of the direct relationship of their mobile-supported work to their performance.

Although they utilize more technology today, all the participants agree that their workload increases. While the various technologies improve their efficiency at work, at the same time they also cause an increase in their workload, which demonstrates the paradoxical situation of using mobile phones in support of work. The workloads or the time spent in the office is beyond the control of the managers, as stated by Rashid:

The time spent in the office depends on the individual and the environment. It relates to human styles. Some bosses call a meeting after five o'clock, which happens a lot here.

\section{Discussion}

The findings from this study enrich the literature on technology's adoption by discussing the technology convergence in the workplace. The nature of the managers' job seems to have the greatest impact on the pat- tern of technology usage in the workplace. Managers utilize many types of mobile applications, with most being utilized to assist in communicating and organizing work. Email is the main medium of communication in support of official communications due to its ability to support both the short and urgent, and the long and detailed information exchanges. It also enables managers to trace communication threads and to send attachments, which are the two most important components in office communications. The study found that the managers' concern about being up-to-date on their latest tasks or assignments is one of the reasons for using emails after work via mobile phones. Being away from the office due to the need to attend meetings or participate in workshops is another cause for using e-mails through a mobile phone.

The level of mobile and fixed technologies' convergence can be categorized based on the influence of several factors. The use of mobile devices can serve as a supplementary technology in cases of low mobility in the workplace, and when work is physically tied to the office. The use of mobile devices can complement fixed technologies in at least two situations: managers use mobile devices to access their e-mails, especially, when they are away from their offices; or make calls as part of the follow-up process necessary to complete managerial tasks. This indicates that a mobile phone could act as an extension to a desktop computer, or it could also function as a traditional phone to make calls. Such usage indicates that keeping up-to-date with on going work, and performing follow-ups are amongst the most important managerial functions. The use of mobile devices can be highly integrated when the use is officially imposed at the workplace, through the implementation of the green office concept, for example, 
or if there is a high personal preference by the managers for mobile gadgets and technologies.

None of the managers utilizes their mobile devices exclusively. The usage of these devices is still combined with fixed technologies to support their managerial tasks. Barriers still exist to using mobile devices exclusively to support managerial work. Mobile device usage by the managers mainly centered on urgent and short communications. For longer detailed communications, fixed technologies are still the preferred equipment. For example, in preparing documents that require significant analysis and thinking, the use of fixed technologies is the favored alternative. This pattern of technology usage generates a new understanding related to managerial work. Managers spend some of their work time thinking and reflecting, and in order to translate this into completed tasks requires both a quiet time and a working space that supports the ease of use of the technology. This finding further extends the concept of the technology-task fit that usually focuses on visible managerial tasks and largely ignores the conceptual part of the work.

Ergonomic issues are also a concern in using mobile devices exclusively, due to their small screen size, which, according to some managers, is visually uncomfortable for reading or writing long documents, and can lead to inefficiency at work. Effectiveness can also suffer due to the cumbersome and uncomfortable use of mobile phone keyboards. Although some of these ergonomic issues can be overcome through the use of peripheral devices, the need to carry these extra devices interferes with mobility. This issue of the small screen size is prevalent for the more senior officers in terms of age, although on the whole, the age factor seems not to be the most important factor for achieving full-in- tegration of fixed-mobile technology usage. Rather, the convergence is mostly influenced by the nature and requirements of the managers' jobs, and in a direct relation is the attributes of the managers' networks, particularly the managers' superiors and colleagues. The third factor is the level of organizational support.

Our findings extend the fit-viability model and the level of digital convergence view (Liang et al. 2007; Yeon and Hwang 2011) by adding the nature of the managers' jobs as a core influential factor. The nature of the managers' jobs is a core factor as decisions to use a particular technology by all the managers included in this study were driven by their need for the technology to be able to support their managerial tasks. This factor also seems to have correlations with other factors of technology convergence, such as a) managers' convergent readiness, b) convergence environment readiness, which include the attributes of those in the managers' networks and organizational factors, and c) convergence technology readiness, which includes the technological factors. Being in the hands of the managers, the use of mobile devices determines the future possibilities for tasks and functions to be supported by mobile technologies. Such usage however, can be supported by a convergence environment that is conducive to the necessity of them completing their managerial tasks.

\section{Conclusion}

Based on our four emergent categories of technology's usage, the mobile device is yet to become a disruptive innovation for managers, as the mobile device is utilized in combination with fixed computing technologies. The utilization of the mobile device has assisted in increasing the efficiency and ef- 
fectiveness of certain managerial tasks. However, fixed technologies are needed to support the conceptual and analytical aspects of managers' work, including the need for reasoning, reflecting, deliberating, judging, considering, and pondering within the process of communication and making decisions. A proper physical working space is also a necessary part of these aspects of managerial work. The thinking and reflecting processes related to the conceptual and analytical tasks of managers seem most appropriately supported by traditional technologies of pen and paper, and a stationary computer. This insight into managerial work and how it is performed enriches our understanding about the functions and activities of managers in general and the contexts of their use of technologies in the workplace.

\section{Ackowledgment}

This study was jointly funded by two research grants: a) Universiti Putra Malaysia's Research University Grant Scheme no.: 06-02-12-1971RU, and b) The Malaysian Ministry of Education's Fundamental Research Grant Scheme no.: 05-02-14-1511FR.

\section{References}

Damanpour, F. 1987. The adoption of technological, administrative, and ancillary innovations: impact of organisational factors. Journal of Management 13 (4): 675-688.

Davis, F. D. 1989. Perceived usefulness, perceived ease of use, and user acceptance of information technology. MIS Quarterly 13 (3): 319-340.

Dewar, R. D., and J. E. Dutton. 1986. The adoption of radical and incremental innovations: an empirical analysis. Management Science 30: 682-695.

Goodhue, D. L., and R. L. Thompson. 1995. Task-technology fit and individual performance. MIS Quarterly 19 (2): 213-236.

Hislop, D., and C. Axtell. 2011. Mobile phones during work and non-work time: a case study of mobile, non-managerial workers. Information and Organisation 21 (1): 41-56.

J. W. Thompson Company. 2013. 13 mobile trends for 2013 and beyond. available at: http:// www.jwtintelligence.com/wp-content/uploads/2013/04/F_JWT_13-Mobile-Trends-for-2013and-Beyond_04.02.13.pdf (accessed 1 September 2014).

Kim, S. H. 2008. Moderating effects of job relevance and experience on mobile wireless technology acceptance: adoption of a smartphone by individuals. Information and Management 45: 387-393.

Liang, T. P., and C. P. Wei. Introduction to the special issue: a framework for mobile commerce applications. International Journal of Electronic Commerce 8 (3): 717.

Liang, T. P., C. W. Huang, Y. H. Yeh, and B. Lin. 2007. Adoption of mobile technology in business: A fitviability model. Industrial Management and Data Systems 107 (8): 1154-1169.

Merriam, S. B. 2009. Qualitative Research: A guide to Design and Implementation. San Francisco, CA: John Wiley $\&$ Sons 
Noori, H. 1990. Managing the Dynamics of New Technology: Issues in Manufacturing Management. Upper Saddle River, NJ: Prentice Hall.

PC Magazine Encyclopaedia. 2014. Digital Convergence. available at: http://www.pcmag.com/encyclopedia/term/41316/digital-convergence (accessed 1 September 2014).

Ramlee, S., K. A. Adam, M. Fuaad Said, S. Kraus, and S. Hänninen. 2010. Start-up, growth and internationalisation of entrepreneurial ventures by the use of service families. International Journal of Management Practice 4 (1): 76-94.

Rogers, E. M. 1995. Diffusion of Innovation (4 $4^{\text {th }}$ ed.). New York, NY: Free Press.

Said, M. F., and K. A. Adham. 2010. Online mobile content innovations and industry structure: implications for firms' strategies. International Journal of Economics and Management 4 (1): 101-119.

Said, M. F., K. A. Adham, and F. Quoquab. 2013. Strategic posturing of Malaysian mobile phone service providers. Pertanika Journal of Social Sciences and Humanities 21 (S): 1-33.

Schadler, T. 2013. 2013 mobile workforce adoption trends. Forrester (available at: http:// www.forrester.com/2013+Mobile+Workforce+Adoption+Trends/fulltext/-/E-RES89442 (accessed 1 September 2014).

Schrott, G., and J. Gluckler. 2004. What makes mobile computer supported cooperative work mobile? Towards a better understanding of cooperative mobile interactions. International Journal of HumanComputer Studies 60: 737-752.

Strauss, A., and J. Corbin. 1990. Basics of Qualitative Research. Newbury Park: CA: Sage.

Tornatzky, L. G., and M. Fleischer. 1990. The Process of Technological Innovation. Maryland: USA: Lexington Book.

Townsend, K., and L. Batchelor. 2005. Managing mobile phones: A work/non work collision in small business. New Technology, Work and Employment 20 (3): 259-267.

Tushman, M. L., and P. Anderson. 1986. Technological discontinuities and organisational environments. Administrative Science Quarterly (31): 439-465.

Valacich, J., and C. Schneider. 2010. Information System Today (4th ${ }^{\text {ed }}$.). New Jersey: NJ: Pearson.

Venkatesh V., and H. Bala. 2008. Technology acceptance model 3 and research agenda on interventions. Decision Sciences 39 (2): 273-315.

Venkatesh, V., and F. D. Davis. 2000. Theoretical extension of the technology acceptance model: Four longitudinal field studies. Management Science 46 (2): 186-204.

Venkatesh, V., M. G. Morris, G. B. Davis, and F. D. Davis. 2003. User acceptance of information technology: Toward a unified view. MIS Quarterly 27: 425-478.

Verizon 2013. 5 Mobile Technology Trends to Watch in 2013. available at: https://www.verizonwireless.com/ insiders-guide/tech-smarts/ (accessed 1 September 2014).

Wolfe, R.A. 1994. Organisational innovation: Review, critique and suggested research directions. Journal of Management Studies 31 (3): 405-431.

Yeon, S. J., and S. H. Hwang. 2011. A digital convergence maturity model: The relative importance of factors. Communications in Computer and Information Science 125: 316-323.

Yoffie, D. B. 1996. Competing in the age of digital convergence. California Management Review 38 (4): 31-53.

York, J., and P. C. Pendharkar. 2004. Human-computer interaction issues for mobile computing in a variable work context. International Journal of Human-Computer Studies 60: 771-797. 
Yuan, Y., N. Archer, C. E. Connelly, and W. Zheng. 2010. Identifying the ideal fit between mobile work and mobile work support. Information and Management 47: 125-137.

Zhou, T., Y. Lu, and B. Wang. 2010. Integrating TTF and UTAUT to explain mobile banking user adoption. Computers in Human Behavior 26 (4): 760-767.

Zhou, T. 2014. Understanding the determinants of mobile payment continuance usage. Industrial Management and Data Systems 114 (6): 936-948. 